Jurnal Pengajian Melayu - JOMAS, Jilid 32(1), 2021: 176-194

\title{
PENTERJEMAHAN DIMENSI SOSIAL KATA TABU DALAM \\ NOVEL THE CATCHER IN THE RYE
}

\author{
(THE TRANSLATION OF TABOO WORDS SOCIAL DIMENSION IN \\ THE CATCHER IN THE RYE NOVEL)
}

\author{
Nur Anis Fadzil \\ nuranis_fadzil@msu.edu.my \\ Management and Science University, Shah Alam \\ Malaysia
}

Anis Shahirah Abdul Sukur

sha_anis@usm.my

Universiti Sains Malaysia, Minden

Malaysia

Received: 25 February 2021; Accepted:12 April 2021

\begin{abstract}
This article is a qualitative study examining social dimensions as a factor influencing the translation of taboo words. The social dimension is a component in sociolinguistics that unravels social information of the community within the communication process. Data were retrieved from a novel titled 'The Catcher in the Rye' by J.D. Salinger in 1951. The translated version in the Malay language was titled 'Wira Ladang', which Zulkifli Ahmad translated in 1999. In this novel, J.D. Salinger narrated the story of a teenage rebellion icon named Holden Caulfield. The social dimension framework by Holmes \& Wilson (2017) and translation strategy by Baker (2011) were applied in this study. The study showed that four social dimensions by Holmes \& Wilson (2017) - social distance, social status, formality and function - are significant factors in determining strategies used by the translator to address taboo words in translation. The researchers also found that textual formality is a dominant social dimension factor influencing the translation of taboo words. However, other social dimensions did influence the selection of strategies by the translator in translating taboo words. This study can serve as a guide for literary work translators to determine the strategy in translating social dimensions that best suit the norms and culture of Malaysian readers.
\end{abstract}

Keywords: social dimension, taboo word, sociolinguistics, translation strategy, culture.

e ISSN 2735 - 1904

https://doi.org/10.22452/JOMAS.vol32no1.11 


\begin{abstract}
Abstrak
Kajian berbentuk kualitatif ini meninjau dimensi sosial sebagai faktor yang mempengaruhi penterjemahan kata tabu. Dimensi sosial ialah komponen sosiolinguistik yang menyampaikan maklumat sosial dalam proses komunikasi. Data kajian terdiri daripada novel yang bertajuk The Catcher in the Rye. Novel hasil tulisan J.D. Salinger ini diterbitkan pada tahun 1951. Versi terjemahan buku ini bertajuk Wira Ladang dan diterjemahkan oleh Zulkifli Ahmad pada tahun 1999. Novel ini mengisahkan perjalanan hidup seorang pemuda bernama Holden Caulfield yang digambarkan dalam bentuk naratif dan deskriptif. Kerangka dimensi sosial oleh Holmes \& Wilson (2017) dan strategi terjemahan oleh Baker (2011) diaplikasikan dalam kajian ini. Dapatan kajian mendapati bahawa empat dimensi sosial oleh Holmes \& Wilson (2017), iaitu sosial, status sosial, tahap keformalan dan fungsian merupakan faktor yang signifikan dalam menentukan strategi yang digunakan oleh penterjemah dalam menangani penterjemahan kata tabu. Pengkaji juga mendapati bahawa tahap keformalan teks merupakan faktor dimensi sosial yang dominan dalam mempengaruhi pemilihan padanan terjemahan bagi kata tabu. Walau bagaimanapun, dimensi sosial yang lain turut mempengaruhi pemilihan strategi terjemahan kata tabu oleh penterjemah. Kajian ini diharapkan dapat menjadi garis panduan kepada penterjemah karya sastera dalam menentukan strategi penterjemahan dimensi sosial yang bertepatan dengan norma dan budaya pembaca sasaran di Malaysia.
\end{abstract}

Kata kunci: dimensi sosial, kata tabu, sosiolinguistik, strategi terjemahan, budaya.

\title{
Pengenalan
}

Van Herk (2012) mentakrifkan sosiolinguistik sebagai kajian tentang hubung kait antara bahasa dan masyarakat. Pandangan ini diperkukuhkan lagi dengan pandangan Holmes \& Wilson (2017) yang mengatakan bahawa sosiolinguistik ialah kajian yang meneliti aspek bahasa dan perkaitannya dengan masyarakat. Bahasa dan masyarakat sememangnya tidak dapat dipisahkan kerana bahasa ialah alat komunikasi yang penting dalam kehidupan manusia dan merupakan cerminan budaya sesuatu masyarakat (Nik Safiah, 1988). Kajian sosiolinguistik dititikberatkan dalam bidang terjemahan kerana aktiviti terjemahan melibatkan pemindahan mesej dalam rumpun bahasa yang terdiri daripada pelbagai spektrum sosial (Lefevere, 1992). Secara tidak langsung, sosiolinguistik yang menelusuri aspek bahasa dan perkaitan sosial dengan kelompok masyarakat dapat memberikan pendedahan yang lebih jelas terhadap isu berkaitan bahasa dan budaya sosial yang terlibat dalam penterjemahan yang melibatkan pasangan bahasa.

Dayang Fatimah (2009) turut berpandangan yang sama dengan menyatakan bahawa aspek sosiolinguistik seperti norma-norma linguistik perlu diambil kira dalam aktiviti menterjemah. Beliau menambah dengan menyatakan bahawa penterjemah perlu peka terhadap ilmu sosiolinguistik sewaktu menghasilkan sesuatu terjemahan. Pandangan ini diutarakan kerana bidang sosiolinguistik memperlihatkan kesesuaian pemilihan dan penggunaan sesuatu bahasa dalam konteks sosiobudaya tertentu. Menurut Cao (2007) pula, kecekapan sosiolinguistik merupakan salah satu komponen kecekapan pragmatik dalam terjemahan yang merujuk pemahaman konvensi sosiolinguistik bagi menjalankan fungsi bahasa. Fungsi ini perlu bertepatan dengan konteks yang diberikan. Tambah sarjana ini lagi, pemilihan bahasa yang sesuai dengan konteks sosiolinguistik yang berbeza akan mengambil kira kesesuaian makna dan bentuk di samping menitikberatkan konteks dua bahasa dan dua budaya yang terlibat dalam proses penterjemahan.

e ISSN 2735 - 1904

https://doi.org/10.22452/JOMAS.vol32no1.11 
Dalam konteks penterjemahan, penterjemah perlu mempunyai pengetahuan sosiolinguistik yang mantap apabila melakukan penterjemahan perkataan yang berunsurkan budaya (Venuti, 1995). Hal ini bertepatan dengan pandangan terdahulu Newmark (1988) yang menyatakan bahawa penterjemah akan menghadapi kesukaran dalam menterjemah isu budaya apabila wujudnya jurang perbezaan budaya antara bahasa yang terlibat dalam penterjemahan. Antara isu yang menimbulkan permasalahan dalam kajian-kajian lepas adalah penterjemahan kata tabu yang berbeza-beza tafsiran mengikut budaya khalayak. Kajian oleh Fadzil \& Abdul Sukur (2020) misalnya membincangkan isu penterjemahan kata tabu mengikut sistem bahasa dan budaya sesuatu bahasa. Kajian-kajian lepas yang dijalankan oleh Coupland (2002), Hofstede (1983) dan Holmes \& Wilson (2017) misalnya memberikan maklumat bahawa dimensi sosial merupakan antara faktor yang menarik untuk ditelusuri. Walaupun kajian tentang dimensi sosial dari perspektif terjemahan masih kurang dijalankan, wujud kepentingan untuk kajian sebegini dijalankan. Hal ini demikian kerana beberapa kajian terdahulu yang dijalankan oleh Nuur Khoirunnisa (2012) dan Rosida (2015) memberikan maklumat bahawa aspek dimensi sosial memberikan perspektif baharu tentang penterjemahan kata tabu apabila dikaji dari sudut perbandingan dua kebudayaan dan bahasa yang berbeza. Oleh itu, makalah ini akan menonjolkan jurang perbezaan budaya bahasa Inggeris dengan bahasa Melayu, iaitu konteks dimensi sosial yang menimbulkan kesukaran kepada penterjemah dalam menterjemah kata tabu yang dikenal pasti. Nilai tambah bagi kajian ini adalah apabila dimensi sosial yang relevan dalam menentukan strategi penterjemahan kata tabu tersebut akan dihuraikan dan dibincangkan dengan kritis dan mendalam.

\section{Sorotan Kajian}

Coupland (2002) mendefinisikan dimensi sosial sebagai kepelbagaian ciri sosial yang berbeza-beza mengikut komuniti masyarakat. Takrifan ini menunjukkan bahawa wujud perkaitan rapat antara bahasa dengan masyarakat. Holmes (2008) menyatakan bahawa dimensi sosial yang mencakupi ruang lingkup yang lebih meluas dapat menjelaskan dengan lebih lanjut faktor sosial yang terlibat dalam sesuatu komunikasi. Hal ini demikian kerana terdapat situasi yang menunjukkan bahawa sesetengah faktor sosial tidak bersesuaian untuk diambil kira dalam pemilihan bahasa seseorang berdasarkan domain sesuatu konteks. Menurut Zahid (2020), dimensi sosial khususnya maklumat sosial peserta komunikasi secara tidak langsung mempengaruhi pemilihan bahasa seseorang dalam sesuatu konteks. Bahasa yang digunakan oleh seseorang dalam pertuturan mahupun penulisan juga adalah berbeza berdasarkan konteks sosial yang hadir dalam sebuah komunikasi (Beden, 2019).

Terdapat beberapa dimensi sosial yang boleh dipertimbangkan dalam pemilihan bahasa. Contohnya Ervin-Tripp (1987) menyatakan terdapat empat faktor yang mempengaruhi pemilihan bahasa dalam interaksi sosial, iaitu latar, peserta komunikasi, topik dan fungsi interaksi. Hofstede (1983) pula memperkenalkan dimensi perbezaan budaya yang setara dengan dimensi sosial yang dikemukakan oleh para sarjana yang lain. Hal ini demikian kerana dimensi sosial dan dimensi budaya tidak mempunyai jurang perbezaan yang ketara. Walhal, konsep sosial dan budaya saling melengkapi dalam bidang sosiolinguistik. Hofstede (1983) telah mengemukakan empat dimensi budaya yang terdiri daripada jarak kuasa, pengelakan keadaan yang tidak pasti, individualisme dan maskulin. Keempat-empat dimensi budaya ini mempunyai perkaitan rapat dengan aspek sosial yang membentuk asas sesebuah organisasi masyarakat. Seterusnya, Romaine (2000) mengelaskan dimensi sosial kepada kelas sosial, umur, jantina, gaya dan rangkaian. Rosida (2015) 
mengemukakan bahawa dimensi sosial merangkumi interaksi sosial, proses sosial, komunikasi sosial dan konteks sosial.

Dimensi sosial dalam pemilihan bahasa yang menjadi tumpuan para sarjana ialah dimensi sosial yang diutarakan oleh Holmes \& Wilson (2017). Pengklasifikasian dimensi sosial oleh Holmes \& Wilson (2017) lebih jelas dan meliputi skop yang meluas, iaitu terdiri daripada jarak sosial, status sosial, tahap keformalan dan fungsian. Kajian dimensi sosial dalam bidang linguistik sudah dijalankan oleh sarjana terdahulu misalnya kajian Latif (2016) terhadap faktor sosial dan dimensi sosial dalam mengekspresikan kemarahan. Dapatan kajiannya menunjukkan bahawa kemarahan merupakan suatu bentuk emosi yang dominan berbanding emosi yang lain dan kemarahan tidak akan tercetus dengan sendirinya. Latif (2016) menyatakan bahawa kemarahan boleh tercetus dengan pelbagai faktor sama ada provokasi, interlokutor dan persekitaran sosial yang lain. Kajian beliau tentang dimensi sosial ini berfokus pada pengaruh persekitaran sosial terhadap ekspresi kemarahan. Dapatan kajian ini menunjukkan bahawa jarak sosial (keintiman) dan peserta (gender dan umur) merupakan faktor yang signifikan dalam menentukan dan mencetuskan ekspresi kemarahan seseorang. Oleh sebab penterjemahan melibatkan dua bahasa dan dua kebudayaan yang tidak sama, faktor dimensi sosial sememangnya menarik untuk dikaji dari perspektif perbandingan antara dua teks.

Tinjauan pengkaji menunjukkan bahawa kajian yang mengkhususkan dimensi sosial dalam bidang penyelidikan terjemahan masih kurang dijalankan. Namun, antara sarjana yang membuat kajian dimensi sosial dalam bidang terjemahan ialah kajian yang dijalankan oleh Nuur Khoirunnisa (2012) dan Rosida (2015). Kajian yang dijalankan oleh Nur Khoirunnisa (2012) meneliti faktor sosial dan dimensi sosial yang mempengaruhi bahasa pertuturan dalam novel bahasa Inggeris, iaitu novel yang diterjemahkan daripada bahasa Indonesia. Kajian Nuur Khoirunnisa (2012) menunjukkan bahawa faktor sosial dan dimensi sosial saling melengkapi dan mempengaruhi pembentukan pertuturan watak dalam novel. Kajian Rosida (2015) pula meninjau fenomena peralihan kod yang didapati dipengaruhi oleh gabungan antara dimensi sosial, dimensi budaya dan dimensi ekonomi. Kajian ini membuktikan bahawa faktor sosial dan dimensi sosial saling melengkapi dalam membentuk kod bahasa untuk berkomunikasi sebagaimana pandangan yang dikemukakan oleh Nuur Khoirunnisa (2012).

Kajian oleh Fadzil (2019) pula menghuraikan dimensi sosial yang mempengaruhi pemilihan strategi terjemahan oleh penterjemah dalam menangani penterjemahan kata tabu. Kajian ini menunjukkan bahawa empat dimensi sosial yang diutarakan oleh Holmes \& Wilson (2017) yang terdiri daripada jarak sosial, status sosial, tahap keformalan dan fungsian secara tidak langsung telah mempengaruhi strategi pemilihan padanan terjemahan bagi kata tabu yang dikenal pasti. Kajian yang dijalankan oleh Fadzil (2019) menunjukkan bahawa kata tabu yang sama boleh diterjemahkan dengan menggunakan strategi terjemahan yang berbeza berdasarkan dimensi sosial yang diteliti dalam analisis data. Fadzil (2019) menyatakan bahawa penterjemah mempunyai pilihan strategi terjemahan yang pelbagai dalam menterjemah kata tabu. Oleh itu, penterjemah tidak lagi terikat dengan strategi pengguguran semata-mata apabila berhadapan dengan situasi ketiadaan padanan kata yang sesuai. Kajian Fadzil (2019) menunjukkan bahawa dimensi sosial sesuai untuk dimanfaatkan dalam bidang terjemahan. 
Berdasarkan sorotan kajian yang telah dijalankan, kajian dimensi sosial dalam bidang terjemahan perlu diperbanyakkan lagi dalam penyelidikan akan datang. Hal ini demikian kerana bahasa dan budaya masyarakat merupakan komponen yang penting dalam aktiviti penterjemahan. Setiap aktiviti penterjemahan akan melibatkan bahasa dan budaya yang saling melengkapi antara satu sama lain. Oleh itu, penterjemah dan penyelidik bidang terjemahan seharusnya menguasai pengetahuan bahasa dan budaya bahasa yang terlibat dalam terjemahan. Masalah ketiadaan padanan yang tepat bagi konteks kata tabu dalam terjemahan dapat diatasi sekiranya penterjemah mempunyai kepakaran dalam dimensi sosial khususnya bagi pasangan bahasa yang terlibat.

\section{Objektif Kajian}

Secara umumnya kajian ini bertujuan untuk meninjau strategi penterjemahan elemen dimensi sosial yang wujud dalam novel The Catcher in the Rye. Oleh itu, objektif kajian ini terbahagi kepada dua, iaitu:

1. Mengenal pasti dan mengkategorikan elemen dimensi sosial bagi kata tabu yang wujud dalam novel The Catcher in the Rye.

2. Mmenentukan strategi terjemahan yang digunakan oleh penterjemah The Catcher in the Rye dalam menterjemahkan elemen dimensi sosial yang mengandungi kata tabu ke dalam bahasa Melayu.

\section{Persoalan Kajian}

Berdasarkan objektif yang dinyatakan, persoalan kajian dibina seperti berikut:

1. Apakah elemen dimensi sosial bagi kata tabu yang wujud dalam novel The Catcher in the Rye?

2. Bagaimanakah penterjemah menangani penterjemahan elemen dimensi sosial yang mengandungi kata tabu dalam novel The Catcher in the Rye ke dalam bahasa Melayu?

\section{Skop Kajian}

Kajian ini mengkaji elemen dimensi sosial yang terlibat dalam penterjemahan novel-novel terpilih. Oleh itu, kajian ini terbatas pada penterjemahan yang berlaku dalam novel kajian, iaitu The Catcher in the Rye serta versi terjemahan, iaitu buku bertajuk Wira Ladang. Bagi memfokuskan kajian, dimensi sosial yang mengandungi kata tabu sahaja yang dianalisis. Langkah ini diambil bagi mengenal pasti jenis-jenis dimensi sosial yang mengandungi penggunaan kata tabu antara watak dalam novel kajian. Pengarang novel ini bernama J.D Salinger yang merupakan seorang penulis berbangsa Amerika. Beliau dilahirkan di New York pada tahun 1919. Novel ini diterbitkan pada tahun 1951 oleh penerbit Little, Brown and Company, Amerika Syarikat. Novel The Catcher in the Rye telah diterjemahkan ke dalam bahasa Melayu dengan tajuk Wira Ladang dan diterbitkan oleh penerbit Dewan Bahasa dan Pustaka pada tahun 1999. Novel ini diterjemahkan oleh Zulkifli Ahmad. Oleh sebab kedua-dua data terdiri daripada novel berbahasa Melayu dan Inggeris, maka 
pasangan bahasa yang dikaji terhad kepada bahasa Melayu dan bahasa Inggeris sahaja. Novel ini dipilih sebagai data kajian kerana mengandungi penggunaan kata tabu yang tinggi di samping kepelbagaian dimensi sosial yang wujud. Menerusi analisis data, pengkaji akan dapat menentukan pengaruh dimensi sosial dalam proses penterjemahan.

\section{Kerangka Kajian}

Kajian ini memanfaatkan pandangan dimensi sosial oleh Holmes \& Wilson (2017) serta Baker (2011) bagi menentukan strategi terjemahan yang digunakan oleh penterjemah. Perincian bagi pandangan daripada kedua-dua sarjana tersebut dijelaskan seperti berikut:

\section{Dimensi Sosial Holmes \& Wilson (2017)}

Empat dimensi sosial yang diaplikasikan dalam penterjemahan kata tabu adalah seperti yang dijelaskan berikut:

\section{a. Jarak Sosial}

Dimensi jarak sosial melibatkan jarak sosial antara peserta komunikasi yang menunjukkan bahawa tahap keakraban mempengaruhi pemilihan bahasa yang digunakan. Jarak hubungan antara peserta yang terlibat dalam komunikasi mempengaruhi kod pemilihan bahasa seseorang. Seseorang peserta komunikasi akan mengambil kira jarak sosial antara satu sama lain sebelum menggunakan sesuatu kod bahasa sama ada dalam pertuturan mahupun penulisan. Oleh itu, jarak sosial merupakan dimensi sosial yang wajar dititikberatkan dalam meninjau penterjemahan kata tabu. Penterjemah perlu mengambil kira jarak sosial antara watak untuk menterjemahkan kata tabu yang terdapat dalam novel kajian.

\section{b. Status Sosial}

Dimensi status sosialmerujukstatusatau darjatseseorangmempengaruhipemilihan bahasa seseorang dalam berkomunikasi. Dimensi ini menunjukkan bahawa orang yang sama berkemungkinan akan menggunakan bahasa berlainan yang bergantung pada status seseorang seperti ibu bapa, guru, pelanggan dan sebagainya. Berdasarkan dimensi status sosial ini, status seseorang mempengaruhi pemilihan bahasa seseorang dalam berkomunikasi. Begitu juga dalam penterjemahan kata tabu, penterjemah juga dianggap mengambil kira status watak yang terdapat dalam novel.

\section{c. Tahap Keformalan}

Dimensi tahap keformalan menunjukkan bahawa latar tempat sama ada formal dan tidak formal mempengaruhi pemilihan bahasa seseorang. Seseorang akan cenderung menggunakan bahasa baku dan standard dalam konteks formal seperti situasi di pejabat, manakala seseorang itu cenderung menggunakan bahasa pasar dalam konteks tidak formal seperti situasi di rumah. Dalam konteks penterjemahan kata tabu, tahap keformalan teks juga merupakan salah satu dimensi yang akan dipertimbangkan oleh penterjemah. Hal ini demikian kerana kata tabu tidak akan digunakan atau diujarkan sewenang-wenangnya dalam sesetengah latar situasi terutamanya situasi yang formal. 


\section{d. Fungsian}

Dimensi fungsian merujuk hala tuju atau tujuan sesebuah interaksi. Dua dimensi fungsian yang diketengahkan oleh Holmes \& Wilson (2017) ialah rujukan dan afektif. Kedua-dua dimensi fungsian ini merangkumi kesemua fungsi interaksi yang lain. Fungsi rujukan merujuk pemberitahuan maklumat sesuatu manakala fungsi afektif merupakan tindakan menzahirkan emosi seseorang. Oleh itu, dimensi fungsian sama ada rujukan dan afektif perlu diambil kira dalam pemilihan kod bahasa seseorang. Dalam konteks penterjemahan kata tabu, dimensi fungsian ini mempengaruhi strategi penterjemah. Hal ini demikian kerana terdapat interaksi yang menunjukkan kata tabu yang terdapat dalam novel digunakan bertujuan untuk memberitahu maklumat dan mengekspresikan emosi watak mahupun kedua-dua fungsian serentak dalam sesebuah komunikasi.

\section{Strategi Terjemahan Baker (2011)}

Empat strategi terjemahan yang diaplikasikan dalam penterjemahan novel kajian adalah seperti di bawah.

\section{a. Menterjemah kata tabu dengan perkataan yang lebih umum}

Penterjemah menggunakan padanan kata yang lebih umum bagi menggantikan kata tabu (kata hiponim) yang telah dilenyapkan dalam teks terjemahan. Strategi ini juga menunjukkan bahawa penterjemah mengambil kira komponen makna bagi kata hiponim dan menggunakan perkataan yang umum dalam terjemahan.

\section{b. Menterjemah kata tabu dengan perkataan yang lebih neutral atau kurang ekspresif}

Penterjemah menggunakan kata yang lebih neutral atau kurang ekspresif dalam menterjemah kata tabu yang tiada padanan dalam bahasa sasaran. Tindakan tersebut dapat mengelakkan penterjemah menghasilkan ekspresi makna yang salah dalam teks terjemahan bagi sesuatu kata tabu yang ingin diterjemahkan.

\section{c. Melakukan parafrasa terhadap kata tabu dengan menggunakan kata yang berkaitan}

Strategi ini digunakan apabila bahasa sumber mempunyai padanan bentuk yang berlainan apabila diterjemahkan dalam bahasa sasaran. Parafrasa dalam konteks ini boleh terdiri daripada penggunaan pernyataan frasa atau kata tunggal sahaja dalam teks terjemahan.

\section{d. Menggugurkan kata tabu}

Penterjemah telah menghilangkan kata tabu ke dalam teks terjemahan. Strategi ini sesuai digunakan apabila penterjemah berhadapan dengan situasi yang menunjukkan kata tabu dalam teks sumber tidak memberi kepentingan yang khusus dalam penceritaan novel. Pengguguran yang dilakukan adalah wajar sekiranya tindakan tersebut tidak menjejaskan mesej keseluruhan penceritaan novel. 


\section{Metodologi Kajian}

Langkah demi langkah bagi menganalisis data berdasarkan kerangka kajian adalah seperti berikut:

1. Mengenal pasti kata tabu

Pengkaji mengekstrak dan mengumpulkan kata tabu yang terdapat dalam teks yang dikaji, iaitu novel The Catcher In The Rye dan buku terjemahan dalam versi bahasa Melayu, iaitu Wira Ladang. Kata tabu merupakan salah satu komponen budaya yang bersangkut paut dengan bahasa dan masyarakat. Takrif dan kategori tabu menurut Battistella (2005) dimanfaatkan dalam kajian ini. Menurut Battistella, kata tabu ialah bahasa tidak sopan (bad language) dan menunjukkan bahawa penuturnya tidak mengikuti peraturan berbahasa. Kata tabu juga merupakan kata yang dikategorikan sebagai bahasa tidak sopan dan boleh dikategorikan kepada kata kesat, kata cabul, kata julukan dan kata lucah.

\section{Kata tabu dikelaskan mengikut dimensi sosial}

Sebanyak 212 kata tabu yang dikumpulkan dan seterusnya dikelaskan mengikut dimensi sosial. Empat dimensi sosial oleh Holmes \& Wilson (2017), iaitu jarak sosial, status sosial, tahap keformalan dan fungsian dimanfaatkan dalam analisis data pada peringkat ini.

\section{Strategi penterjemahan kata tabu dikenal pasti}

Seterusnya setiap contoh kata tabu dianalisis bagi mengenal pasti strategi yang dimanfaatkan oleh penterjemah bagi menghasilkan terjemahan dalam bahasa Melayu. Strategi terjemahan Baker (2011), iaitu menterjemah kata tabu dengan perkataan yang lebih umum, menterjemah kata tabu dengan perkataan yang lebih neutral atau kurang ekspresif, melakukan parafrasa terhadap kata tabu dengan menggunakan kata yang berkaitan, dan menggugurkan kata tabu dimanfaatkan dalam analisis data. Ringkasan bagi metodologi kajian adalah seperti dalam Rajah 1 berikut.
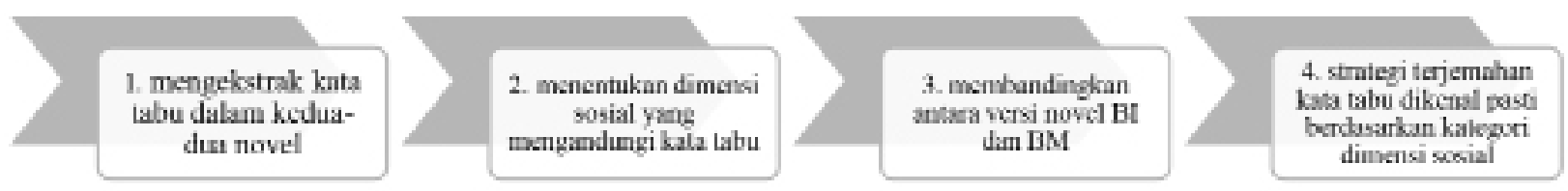

Rajah 1

Metodologi Kajian

\section{Perbincangan dan Analisis Data}

Data kajian terdiri daripada 212 kata tabu yang terdiri daripada kata julukan, kata kesat, kata cabul dan kata lucah. Seterusnya kata tabu dikelaskan mengikut kerangka dimensi sosial oleh Holmes \& Wilson (2017). Analisis data menunjukkan bahawa empat dimensi sosial yang dikemukakan oleh Holmes \& Wilson (2017) sesuai dimanfaatkan dalam kajian penterjemahan kata tabu. Maklumat 
bilangan dan peratusan mengikut jenis dimensi sosial seperti yang disenaraikan dalam Jadual 1 berikut:

Jadual 1

Jenis dan bilangan dimensi sosial

\begin{tabular}{|l|l|}
\hline Jenis Dimensi Sosial & Jumlah (\%) \\
\hline Jarak Sosial & $55(26 \%)$ \\
\hline Status Sosial & $13(6 \%)$ \\
\hline Tahap keformalan & $103(49 \%)$ \\
\hline Fungsian & $41(19 \%)$ \\
\hline
\end{tabular}

Jadual 1 menunjukkan bahawa tahap keformalan teks merupakan faktor dominan dalam penterjemahan kata tabu, iaitu sejumlah 103 kata tabu daripada jumlah keseluruhan. Kemudian, diikuti dengan faktor dimensi sosial yang kedua dan ketiga tertinggi, iaitu jarak sosial dan fungsian yang masing-masing berjumlah 55 kata tabu dan 41 kata tabu. Faktor status sosial merupakan dimensi yang paling minimum, iaitu sejumlah 13 kata tabu daripada keseluruhan data. Perbincangan lanjut berserta contoh yang sesuai bagi setiap faktor dimensi sosial yang dianggap mempengaruhi penterjemahan kata tabu akan dilakukan pada bahagian seterusnya. Walau bagaimanapun, hanya beberapa contoh yang signifikan dalam kajian yang akan dibincangkan dalam analisis. Contohcontoh yang signifikan dalam konteks ini merujuk data yang mewakili setiap dimensi sosial serta melibatkan variasi dalam penggunaan strategi terjemahan.

\section{a. Jarak Sosial}

Bagi dimensi jarak sosial, didapati bahawa terdapat beberapa skala keakraban hubungan antara watak dalam novel sama ada paling dekat atau jauh yang dianggap mempengaruhi pemilihan padanan kata oleh penterjemah dalam menterjemah kata tabu. Antara jenis hubungan yang dikenal pasti ialah (1) hubungan watak dengan ahli keluarga; (2) hubungan watak dengan rakan; dan (3) hubungan watak dengan orang yang tidak dikenali. Jika dilihat dari sudut perspektif keakraban hubungan, didapati bahawa jenis hubungan (1) dan (2) menunjukkan jarak hubungan yang lebih rapat berbanding dengan jenis hubungan (3) yang mempunyai jarak hubungan yang jauh. Oleh itu, penterjemah telah menggunakan strategi yang berlainan dalam menterjemah kata tabu yang dikenal pasti. Contohnya adalah seperti berikut:

\section{Contoh 1}

Teks Sumber: They're nice and all - I'm not saying that - but they're also touchy as hell.

Teks Sasaran: Sebenarnya mereka baik - tetapi mereka mudah benar tersinggung. 
Contoh 1 ialah kata tabu yang diterjemahkan dengan mengambil kira dimensi jarak sosial yang terdapat dalam penceritaan novel. Jarak sosial yang terdapat dalam contoh 1 ialah jarak antara Holden dengan ibu bapanya, iaitu hubungan keluarga yang rapat. Berdasarkan contoh 1, didapati bahawa terdapat penggunaan frasa tabu bahasa Inggeris iaitu frasa as hell dalam ayat tersebut. Penterjemah telah mengambil kira jarak hubungan antara anak dengan ibu bapa dalam konteks budaya masyarakat Malaysia menterjemah kata tabu tersebut. Penterjemah menterjemah kata tabu dengan menggunakan kata yang lebih umum, iaitu frasa 'mudah benar' dalam terjemahan. Frasa 'mudah benar' adalah bersifat umum dan boleh digunakan dalam mana-mana konteks situasi. Oleh itu, padanan frasa 'mudah benar' adalah memadai bagi frasa as hell kerana frasa tersebut menghuraikan makna bagi frasa as hell yang menunjukkan penegasan terhadap ayat yang menyatakan ibu bapa Holden sangat mudah tersinggung dengan sesetengah perkara. Padanan seperti 'mudah sentap' atau 'sensitif gila' hanya memberikan konotasi kurang sopan terhadap pihak yang digambarkan di samping memberikan imej kurang baik terhadap penutur ayat tersebut. Contoh ini juga menunjukkan bahawa penterjemah menggantikan kata tabu dengan perkataan yang lebih umum dalam teks terjemahan bagi mengelakkan penerapan budaya yang kurang sopan kepada masyarakat Melayu yang menerapkan nilai murni apabila seorang anak perlu menuturkan atau menceritakan perkara yang baik tentang ibu bapa mereka.

\section{Contoh 2}

Teks Sumber: We horsed around a little bit in the cab on the way over to the theater. At first, she didn't want to, because she had lipstick on and all, but I was being seductive as hell and she didn't have any alternative.

Teks Sasaran: Kami bercumbu di dalam teksi semasa perjalanan ke panggung. Pada mulanya dia enggan sebab dia memakai gincu bibir, tetapi aku begitu menggoda sekali dan dia tiada pilihan.

Contoh 2 menunjukkan penceritaan Holden mengenai tingkah laku antara dia dengan Sally Hayes. Berdasarkan contoh 2, dapat dilihat bahawa jarak hubungan intim antara Holden dengan salah seorang rakan perempuannya, iaitu Sally Hayes mempengaruhi penterjemah semasa menterjemah frasa tabu as hell ke dalam teks terjemahan. Frasa as hell dalam contoh 2 juga digunakan sebagai penegasan oleh Holden dan tidak sesuai diterjemahkan secara literal menjadi 'seperti neraka'. Oleh itu, penterjemah telah menggunakan kata yang lebih umum bagi menggantikan frasa tabu dalam teks terjemahan. Frasa seductive as hell telah diterjemahkan kepada 'begitu menggoda sekali' dalam teks terjemahan merupakan pilihan penterjemah yang sesuai dengan jarak hubungan yang intim antara Holden dengan rakan perempuannya. Hal ini demikian kerana mesej asal teks sumber dapat disampaikan dengan baik, iaitu unsur penegasan dikekalkan walaupun kata tabu telah digantikan dengan perkataan yang umum dalam teks terjemahan. Tindakan penterjemah tersebut

telah memperlihatkan bahawa penulis tidak menggunakan kata tabu apabila membicarakan tentang tingkah laku Holden bersama-sama rakan perempuannya itu. 
Contoh 1 dan 2 menunjukkan watak Holden mempunyai jarak hubungan yang rapat dengan kedua-dua watak yang ditonjolkan dalam konteks penceritaan. Contoh 1 berkisar hubungan ahli keluarga manakala Contoh 2 ialah hubungan antara pasangan kekasih. Oleh itu, didapati bahawa penterjemah telah menggantikan penggunaan kata tabu iaitu frasa as hell dalam teks sumber dengan kata yang lebih umum ke dalam teks terjemahan. Hal ini menunjukkan bahawa penterjemah cuba untuk mengurangkan penggunaan kata tabu terhadap individu yang mempunyai hubungan yang rapat antara watak dalam novel. Seperkara yang perlu dipertimbangkan ialah perkataan hell membawa maklumat kata tabu apabila dirujuk pada kategori tabu menurut Battistella (2005). Namun apabila diperinci dalam konteks Barat, perkataan yang sama boleh membawa unsur penegasan semata-mata dan tidak membawa maksud sesuatu yang lucah atau kurang sopan. Frasa as hell juga sesuai diterjemahkan dengan menggunakan strategi yang berlainan berdasarkan dimensi jarak yang terlibat dalam penceritaan novel. Misalnya seperti dalam Contoh 3 berikut:

\section{Contoh 3}

Teks Sumber: Then, when she was all done whispering and being cute as hell, she'd sing some dopey song, half in English and half in French, and drive all the phonies in the place mad with joy.

Teks Sasaran: Kemudian, sebaik-baik sahaja dia habis berbisik dan mengada-ngada, dia akan menyanyi sebuah lagu bodoh, separuh dalam bahasa Inggeris dan separuh dalam bahasa Perancis, dan membuatkan semua orang yang suka berpura-pura di tempat itu begitu gembira sekali.

Contoh 3 menunjukkan penceritaan Holden mengenai salah seorang penyanyi di bar yang dikunjunginya. Berdasarkan contoh ini, didapati jarak hubungan antara Holden dengan orang yang tidak rapat dengannya mempengaruhi penterjemah dalam menterjemahkan frasa cute as hell yang terdapat dalam teks sumber. Dapat dilihat bahawa penterjemah tidak menterjemah frasa cute as hell kepada 'sangat comel sekali' atau 'terlalu comel' sepertimana contoh 1 dan 2 yang menunjukkan bahawa penterjemah menggunakan kata yang lebih umum dalam menterjemah frasa tersebut. Akan tetapi, contoh 3 menunjukkan bahawa penterjemah telah memilih untuk menterjemah frasa cute as hell kepada kata 'mengada-ngada' dalam teks terjemahan. Dapat dianalisis dalam konteks ini bahawa penterjemah telah mengaplikasikan strategi parafrasa dengan menggunakan kata yang berkaitan dalam menterjemahkan frasa cute as hell ke dalam teks terjemahan. Jarak hubungan yang jauh antara Holden dan penyanyi bar tersebut mempengaruhi penterjemah dalam memilih padanan yang sesuai ke dalam teks terjemahan. Hal ini menunjukkan bahawa penterjemah dapat menggambarkan perspektif Holden yang menganggap orang yang tidak rapat dengannya seperti penyanyi bar tersebut mempunyai tingkah laku yang buruk. Strategi terjemahan ini masih berjaya mengekalkan mesej walaupun menggunakan padanan terjemahan yang berbeza dalam bahasa Melayu. Konteks keseluruhan perenggan ayat memberikan maklumat bahawa Holden kurang rapat dan tidak gemar kepada individu yang sedang digambarkannya. 
Contoh 1, 2, dan 3 telah menunjukkan bahawa dimensi jarak sosial perlu diambil kira dalam penterjemahan kata tabu. Didapati bahawa penterjemah berkemungkinan besar meneliti jarak hubungan yang terdapat dalam konteks penceritaan sama ada dekat mahupun jauh apabila berhadapan dengan kata tabu yang dikenal pasti dalam novel sumber. Oleh itu, jarak sosial merupakan dimensi sosial yang perlu dititikberatkan dalam penterjemahan kata tabu. Penterjemah didapati cenderung mengekalkan kata tabu yang berkonotasi negatif apabila wujud hubungan yang tidak rapat antara watak utama dengan individu yang digambarkan olehnya. Selain itu, situasi dialog itu dituturkan juga memainkan peranan dalam memilih strategi terjemahan yang bersesuaian.

\section{b. Status sosial}

Status sosial juga merupakan salah satu dimensi sosial yang dititikberatkan dalam penterjemahan kata tabu. Status sosial watak dalam novel sama ada lebih tinggi mahupun rendah juga mempengaruhi penterjemah dalam membuat pilihan padanan terjemahan bagi kata tabu yang dikenal pasti. Berdasarkan penelitian, antara status sosial yang di ambil kira dalam penterjemahan kata tabu ialah (1) pelajar dengan jurulatih/guru; dan (2) remaja dengan orang yang lebih tua. Dimensi status sosial ini memperlihatkan watak yang mempunyai status lebih rendah akan menghormati watak yang mempunyai status lebih tinggi dalam konteks penceritaan novel. Perbincangan lanjut bagi dimensi status sosial adalah seperti yang dijelaskan dalam contoh yang berikut:

\section{Contoh 4}

Teks Sumber: For instance, they had this headmaster, Mr. Haas, that was the phoniest bastard I ever met in my life.

Teks Sasaran: Misalnya, Pengetua sekolah itu, Encik Haas, merupakan seorang yang paling hipokrit yang pernah kutemui dalam hidupku.

Contoh 4 menunjukkan bahawa dimensi status sosial mempengaruhi penterjemah dalam menterjemah kata tabu yang dikenal pasti. Didapati bahawa terdapat penggunaan kata tabu, iaitu bastard dalam teks sumber yang digunakan oleh Holden ditujukan kepada pengetua di sekolahnya yang terdahulu. Konteks teks sumber menunjukkan bahawa Holden mempunyai tanggapan yang buruk terhadap pengetua di sekolahnya. Holden menganggap pengetua itu seorang yang berperangai teruk dan hipokrit. Berdasarkan penelitian, penterjemah telah mengambil kira status sosial dalam menterjemah kata bastard ke dalam teks terjemahan. Ekoran daripada status pekerjaan Encik Haas yang lebih tinggi, iaitu sebagai pengetua sekolah Holden, penterjemah telah mengambil keputusan untuk menggugurkan kata tabu yang terdapat dalam teks sumber apabila diterjemahkan ke dalam bahasa sasaran. Walaupun kata tabu telah digugurkan dalam teks terjemahan, penterjemah masih dapat mengekalkan sebahagian daripada makna asal konteks teks sumber. Pembaca juga masih mendapat maklumat bahawa Encik Haas seorang yang hipokrit, iaitu seorang yang berpura-pura tanpa maklumat penegasan menerusi kata tabu dalam ayat tersebut. 
Contoh 5

Teks Sumber: She looked like she might have a pretty damn good idea of what a bastard she was the mother of.

Teks Sasaran: Dia kelihatan seperti seseorang yang tahu benar perangai anaknya.

Contoh 5 menunjukkan Holden memberitahu kepada pembaca bahawa ibu Ernest masak benar atau benar-benar mengetahui akan perangai anaknya. Hal ini menunjukkan bahawa penterjemah mengambil kira status sosial dalam memilih padanan kata bagi kata tabu yang terdapat dalam teks sumber. Penterjemah didapati mengambil kira status ibu Ernest yang lebih berusia daripada Holden dalam memilih padanan kata yang sesuai bagi kata 'bastard' yang terdapat dalam teks sumber. Penterjemah didapati mengambil keputusan menterjemah kata 'bastard' kepada kata yang lebih umum iaitu 'anaknya' dalam teks terjemahan. Penggunaan perkataan yang umum dalam teks terjemahan telah melenyapkan bentuk kata tabu dan menonjolkan sikap hormat Holden terhadap orang yang lebih tua dalam teks versi bahasa Melayu. Tindakan ini adalah boleh diterima dan tidak menyebabkan kekeliruan terhadap pembaca kerana kata 'anaknya' merujuk orang yang sama dengan orang yang digambarkan dalam teks sumber.

Contoh 4 dan 5 telah menunjukkan bahawa status sosial juga mempengaruhi penterjemah dalam menterjemah kata tabu yang dikenal pasti. Penterjemah mengambil kira status sosial watak dalam novel seperti status pekerjaan dan umur dalam menterjemah kata tabu. Oleh yang demikian, strategi terjemahan yang digunakan dalam menterjemah kata tabu adalah berbeza-beza mengikut status sosial watak-watak dalam novel. Langkah ini juga memberikan maklumat bahawa wujud perbezaan antara budaya Melayu dan budaya Inggeris yang diperlihatkan menerusi penggunaan bahasa yang dipertuturkan.

\section{c. Tahap keformalan}

Tahap keformalan merujuk jenis interaksi sama ada bersifat formal atau tidak formal. Dimensi ini menunjukkan bahawa jenis interaksi sama ada formal dan tidak formal sedikit sebanyak mempengaruhi penterjemah dalam menterjemah kata tabu yang dikenal pasti. Penelitian menunjukkan bahawa novel yang dikaji merupakan teks kesusasteraan remaja yang banyak menggunakan bahasa santai dan situasi tidak formal. Oleh itu, penterjemah juga meneliti latar situasi yang terdapat dalam penceritaan novel apabila menterjemah kata tabu. Walaupun kebanyakan latar situasi dalam novel adalah bersifat tidak formal, penterjemah telah menggunakan strategi yang berlainan dalam menterjemah kata tabu berdasarkan situasi tidak formal yang berbeza-beza.

\section{Contoh 6}

Teks Sumber: "What the hellya reading?" he said. "Goddam book."

Teks Sasaran: "Apakah yang kaubaca?” dia bertanya. "Bukulah." 
Contoh 6 merupakan perbualan antara Holden dan rakannya, Ackley di bilik asrama mereka. Dapat dilihat bahawa terdapat penggunaan kata tabu dalam perbualan yang santai dan tidak formal antara Holden dan Ackley. Berdasarkan contoh 6, penterjemah telah mengambil keputusan untuk menggugurkan kata hell dan goddam dalam teks terjemahan kerana kata tabu tersebut tidak mempunyai kepentingan yang khusus dalam penceritaan novel berbahasa Melayu. Kata-kata tabu tersebut yang digunakan oleh watak dalam novel merupakan salah satu bentuk percakapan yang santai dalam latar situasi yang tidak formal dalam bahasa Inggeris. Maklumat penggunaan kata tabu dalam dimensi sosial berkenaan tidak diterjemahkan ke dalam bahasa Melayu memandangkan budaya Timur lazimnya tidak mengguna pakai kata tabu sebagai bentuk bahasa lisan antara sahabat yang akrab.

\section{Contoh 7}

Teks Sumber: Twice, when the goddam cab stopped short in traffic, I damn near fell off the seat.

Teks Sasaran: Dua kali, apabila teksi jahanam itu berhenti, semasa dalam perjalanan, aku hampir jatuh daripada tempat duduk.

Contoh 7 menunjukkan Holden sedang menceritakan kepada pembaca mengenai situasi kurang menyenangkan yang berlaku sewaktu dia berada di dalam sebuah teksi. Berdasarkan analisis data, tahap keformalan telah mempengaruhi penterjemah dalam menterjemah kata tabu. Penterjemah mengambil kira latar situasi tidak formal, iaitu di dalam teksi yang memaparkan respons spontan Holden menggunakan kata goddam apabila teksi yang dinaikinya berhenti di lampu isyarat sehingga menyebabkan dia hampir terjatuh dari tempat duduk. Penggunaan kata keagamaan, iaitu nama Tuhan dalam situasi yang tidak sepatutnya merupakan kata tabu (Battistella, 2005). Oleh itu, penterjemah telah menggunakan kata yang lebih neutral dan kurang ekspresif dalam teks terjemahan bagi menggantikan kata tabu yang menggunakan kata keagamaan dalam situasi yang tidak sepatutnya. Penterjemah telah menterjemahkan kata goddam kepada kata yang lebih neutral atau kurang ekspresif, iaitu 'jahanam' dalam teks terjemahan. Hal ini menunjukkan bahawa penterjemah telah mengekalkan bentuk ekspresi kata tabu teks sumber dalam bentuk yang berbeza dalam teks terjemahan. Contoh ini juga memberikan maklumat bahawa strategi terjemahan kata tabu adalah pelbagai dan penterjemah tidak semestinya memilih untuk menggugurkan kata tabu sahaja.

\section{Contoh 8}

Teks Sumber: I saw it in the window of this sports store when we got out of the subway, just after I noticed I'd lost all the goddam foils.

Teks Sasaran: Aku ternampak topi ini dalam cermin pameran kedai menjual alat-alat sukan apabila kami keluar dari stesen kereta api bawah tanah, setelah aku tersedar bahawa aku kehilangan semua pedang-pedang bedebah itu. 
Contoh 8 juga menunjukkan tahap keformalan mempengaruhi strategi penterjemah dalam menangani kata tabu. Kata tabu, iaitu kata goddam juga digunakan oleh Holden apabila memberitahu kepada pembaca mengenai situasi yang berlaku di dalam kereta api. Holden menggunakan kata goddam untuk merujuk pedang-pedang yang tertinggal di dalam kereta api. Ujaran ini menunjukkan bahawa sememangnya Holden selesa menggunakan kata tabu apabila dia tidak berpuas hati akan sesuatu perkara dan melibatkan situasi yang tidak formal. Penterjemah telah menterjemah kata goddam kepada kata yang lebih umum, iaitu 'bedebah' dalam teks terjemahan. Kata 'bedebah' kebiasaannya digunakan untuk menunjukkan seseorang itu berkelakuan teruk. Namun begitu, kata 'bedebah' masih dapat menyampaikan maksud penulis asal. Walaupun kata 'bedebah' agak kurang sesuai untuk digunakan bagi merujuk akan perwatakan sesuatu benda, akan tetapi kata tersebut diterima kerana dapat memaparkan bentuk percakapan Holden yang santai dan kasar.

Perbincangan dalam contoh 6, 7, dan 8 menunjukkan bahawa kata tabu, iaitu kata goddam diterjemahkan dengan menggunakan strategi yang berbeza walaupun ketiga-tiga contoh tersebut merujuk kepada jenis kata yang sama dan latar situasi yang tidak formal. Hal ini menunjukkan bahawa satu kata tabu diterjemahkan dengan cara yang berbeza walaupun kebanyakan penceritaan novel adalah bersifat tidak formal. Penterjemah didapati mengamati setiap situasi tidak formal yang terlibat dan memilih strategi yang berlainan bagi menghasilkan padanan terjemahan kata tabu yang pelbagai dalam teks terjemahan. Oleh itu, penterjemah tidak terlalu bergantung pada strategi terjemahan yang sama sahaja dalam menangani penterjemahan kata tabu.

\section{d. Fungsian}

Dimensi fungsian merupakan dimensi sosial yang juga secara tidak langsung mempengaruhi pemilihan strategi penterjemah dalam menterjemah kata tabu. Dimensi fungsian akan memperlihatkan tujuan sesebuah interaksi mempengaruhi pemilihan padanan terjemahan yang sesuai bagi kata tabu yang ingin diterjemahkan. Melalui dimensi fungsian ini, penterjemah akan mengambil kira dua dimensi fungsian, iaitu rujukan dan afektif. Kedua-dua dimensi fungsian ini akan memperlihatkan corak strategi terjemahan yang berlainan bagi menterjemahkan kata tabu walaupun melibatkan kata tabu yang sama.

\section{Contoh 9}

Teks Sumber: Goddam money. It always ends up making you blue as hell.

Teks Sasaran: $\underline{\text { Jahanam }}$ betul duit. Ia selalu membuatkan kita menjadi sugul.

Contoh 9 menunjukkan dimensi fungsian mempengaruhi penterjemah dalam menentukan strategi terjemahan yang akan digunakan bagi menterjemahkan kata tabu yang terdapat dalam teks. Kata goddam yang digunakan oleh Holden dalam contoh 9 merupakan kata tabu berbentuk kata cabul yang digunakan untuk memberitahu maklumat bahawa kekurangan duit menyebabkan hidup seseorang gelisah dan mengekspresikan emosi Holden yang kesal dengan keadaan duit yang tidak mencukupi. Penterjemah telah menterjemah kata goddam kepada kata 'jahanam' dalam 
teks terjemahan. Hal ini menunjukkan bahawa penterjemah telah mengekalkan bentuk ekspresi tabu kata sumber dengan menggunakan bentuk ekspresi yang neutral dalam teks terjemahan. Pengguguran kata tabu ini akan menyebabkan pembaca kurang jelas dengan isu yang diujarkan oleh penutur. Pembaca sasaran bukan hanya dapat memahami maksud teks asal, malah pembaca dapat merasai kesan emosi yang digambarkan dalam teks sumber. Selain itu, frasa blue as hell juga diberikan padanan satu kata yang tepat, iaitu 'sugul' bagi menyampaikan perasaan Holden dalam situasi berkenaan.

\section{Contoh 10}

Teks Sumber: The sonuvabitch could whistle better than anybody I ever heard.

Teks Sasaran: Bedebah itu boleh bersiul lebih baik daripada sesiapa pun yang pernah kudengar.

Contoh 10 menunjukkan penterjemah mengambil kira dimensi fungsian dalam memilih strategi terjemahan apabila menterjemah kata tabu. Didapati bahawa contoh 10 juga memperlihatkan dua dimensi fungsian, iaitu rujukan dan afektif mempengaruhi pemilihan padanan terjemahan oleh penterjemah dalam menterjemah kata sonuvabitch. Kata sonuvabitch yang digunakan oleh Holden adalah bertujuan untuk menyampaikan maklumat bahawa Ackley mempunyai satu kelebihan, iaitu pandai bersiul di samping meluahkan memaparkan emosi Holden yang tidak sukakan perangai Ackley yang dianggap menjengkelkan. Dengan mengambil kira dua dimensi fungsian, penterjemah telah menggunakan kata yang lebih neutral atau kurang ekspresif, iaitu kata 'bedebah' dalam teks terjemahan. Padanan terjemahan yang terhasil dapat menyampaikan maklumat bahawa Ackley pandai bersiul dan menzahirkan emosi Holden yang kurang senang dengan sikap Ackley.

Contoh 9 dan 10 menunjukkan bahawa fungsi sesebuah interaksi juga merupakan dimensi sosial yang mempengaruhi pemilihan strategi terjemahan yang digunakan oleh penterjemah dalam menterjemah kata tabu. Melalui dimensi ini, penterjemah perlu menentukan strategi terjemahan yang dapat memenuhi kehendak fungsi sesebuah interaksi sama ada rujukan mahupun afektif atau kedua-duanya sekali. Penguasaan dimensi fungsian ini dapat membantu penterjemah dalam menghasilkan teks terjemahan yang dapat memberikan kefahaman yang jelas kepada pembaca sasaran tentang apa-apa yang disampaikan oleh penulis teks sumber.

\section{Kesimpulan}

Dimensi sosial merupakan komponen sosiolinguistik yang wajar dipertimbangkan dalam bidang terjemahan, khususnya apabila melibatkan situasi penggunaan kata tabu. Sebanyak 212 kata tabu digunakan dalam novel, yang turut membawa maklumat bahawa sebanyak 212 dimensi sosial yang terlibat. Makalah ini juga membuktikan bahawa 212 dimensi sosial berkenaan sesuai dikategorikan mengikut empat dimensi sosial yang terdiri daripada jarak sosial, status sosial, tahap keformalan dan fungsian. Oleh itu, penelitian pengkaji mendapati bahawa keempat-empat dimensi sosial yang dikemukakan oleh Holmes dan Wilson (2017) sesuai diambil kira oleh penterjemah teks sastera dalam menentukan strategi terjemahan. Keempat-empat dimensi ini dibincangkan 
menerusi kehadiran kata tabu dalam teks versi bahasa Inggeris dan bahasa Melayu. Analisis perbandingan antara dua bahasa secara tidak langsung memberikan nilai tambah terhadap kajian daripada perspektif terjemahan ini.

Dimensi sosial lazimnya digunakan untuk menghuraikan maklumat sosial yang mempengaruhi pemilihan bahasa seseorang. Namun begitu, dimensi sosial yang mencakupi ruang lingkup sosial yang meluas juga dapat dimanfaatkan dalam bidang kajian penterjemahan. Penterjemah telah menterjemahkan kata tabu yang terdapat dalam novel dengan menggunakan strategi yang pelbagai. Hal ini menunjukkan bahawa penterjemah sememangnya secara tidak langsung menitikberatkan faktor dimensi sosial yang bersesuaian dengan konteks latar penceritaan novel dalam memilih padanan terjemahan bagi kata tabu yang dikenal pasti. Selain mempertimbangkan faktor latar belakang watak utama, iaitu Holden, penterjemah didapati mempertimbangkan (i) latar belakang individu yang bertutur dengan Holden, (ii) perasaan Holden semasa menuturkan dialog seperti sedang marah, gembira, bergurau dan bersedih, (iii) jarak perhubungan antara Holden dan individu yang terlibat seperti rakan-rakan, guru, adik perempuan, teman wanita, ibu bapa dan orang asing, serta (iv) tempat watak-watak berkenaan berkomunikasi seperti dalam kenderaan seperti kereta api dan kereta atau latar tempat yang lebih meluas seperti rumah Holden, rumah guru, asrama, rumah tumpangan dan bar.

Analisis data juga memberikan maklumat bahawa strategi terjemahan oleh Baker (2011) sesuai dimanfaatkan dalam penterjemahan kata tabu berdasarkan empat dimensi sosial yang dihuraikan. Keupayaan penterjemah mengaplikasikan pelbagai strategi menonjolkan bahawa terdapat banyak strategi yang boleh diaplikasikan bagi menangani masalah penterjemahan kata tabu selain memilih untuk mengaplikasikan strategi pengguguran. Oleh itu, dapat disimpulkan bahawa gabungan pendekatan sosiolinguistik dan terjemahan telah memantapkan dapatan kajian bagi makalah ini. Tambahan pula, kajian ini juga memberi perspektif baharu dalam bidang terjemahan. Pengkaji tidak hanya meninjau penterjemahan kata tabu dari segi strategi terjemahan semata-mata serta kategori kata tabu mengikut budaya Inggeris-Melayu, malahan pengkaji meneliti faktor dimensi sosial dalam penterjemahan kata tabu. Kajian ini juga secara tidak langsung merintis jalan kepada penyelidik akan datang untuk mengkaji faktor dimensi sosial dalam penterjemahan melalui genre teks yang berbeza.

\section{Rujukan}

Baker, M. (2011). In other words: A coursebook on translation. London \& New York: Routledge.

Battistella, E.L (2005). Bad language: Are some words better than others? New York: Oxford University Press.

Cao, D. (2007). Translating law. Clevedon, England: Multilingual Matters.

Coupland, N. (2002). Language, situation, and the relational self: Theorizing dialect-style in sociolinguistics. In P. Eckert \& J. Rickford (Eds), Style and Sociolinguistic Variation (pp. 185-210). Cambridge: Cambridge University Press. 
Dayang Fatimah Haji Awang Chuchu. (2009). Norma-norma Linguistik dalam Terjemahan. In Hasuria Che Omar dan Rokiah Awang (eds.). Kelestarian Bidang Penterjemahan (116134). Kuala Lumpur: Persatuan Penterjemah Malaysia.

Ervin-Tripp, S. M. (1987). Sociolinguistic rules of address. In A. K. Pugh, Barbara Mayor (Ed.), Language, Communication and Education (162). New Hampshire: Open University.

Fadzil, N. A. (2019). Analisis strategi penterjemahan kata tabu dalam novel The Catcher In The Rye. (Tesis Ijazah Sarjana Sastera), Universiti Sains Malaysia, Pulau Pinang.

Fadzil, N. A., \& Abdul Sukur, A. S. (2020). Strategi penterjemahan kata tabu dalam teks sastera. PENDETA: Journal of Malay Language, Education and Literature, 11(2), 70-84.

Hofstede, G. (1983). The cultural relativity of organizational practices and theories. Journal of International Business Studies, 14(2), 75-89.

Holmes, J. (2008). An introduction to sociolinguistic. Harlow, England: Pearson/Longman.

Holmes, J., \& Wilson, N. (2017). An introduction to sociolinguistic. London \& New York: Routledge.

Latif Amrullah. (2016). Social factors and social dimensions in expressing anger. Prasasti, 427431. Surakarta: Program Studi S3 Linguistik PPs UNS. Retrieved from https://jurnal.uns. ac.id/prosidingprasasti/article/viewFile/1562/1452.

Lefevere, A. (1992) Translation, rewriting and the manipulation of literary fame. London: Routledge.

Newmark, P. (1988). A textbook of translation. New York: Prentice Hall.

Nik Safiah Karim. (1988). Sosiolinguistik bahasa Melayu dan pengajaran. Kuala Lumpur: Fajar Bakti.

Nuur Khoirunnisaa. (2012). Analisis faktor sosial dan dimensi sosial pada tindak tutur dalam novel The Rainbow Troops karya Andrea Hirata: Kajian sosiolinguistik. (Tesis Ijazah Sarjana Sastera). Universitas Widyatama, Bandung, Indonesia. Retrieved from https://repository. widyatama.ac.id/xmlui/handle/123456789/3970.

Romaine, S. (2000). Language in society: An introduction to sociolinguistics. New York: Oxford University Press.

Rosida Tiurma Manurung. (2015). Analisis dimensi sosial, budaya, dan ekonomi dalam fenomena alih kode di Rusunawa. Language Maintenance and Shift, 369-373.

Salinger, J. D. (1991). The catcher in the rye. New York: Little, Brown and Company.

Salinger, J. D. (1999). Wira ladang (penterjemah Zulkifli Ahmad). Kuala Lumpur: Dewan Bahasa dan Pustaka.

Beden, S. (2019). Prinsip dan strategi kesantunan penulisan dalam artikel ruangan agenda bahasa. Issues in Language Studies, 8(1), 105-129. 
Van Herk, G. (2012). What is sociolinguistics? United Kingdom: Wiley-Blackwell.

Venuti, L. (1995) The translator's invisibility. A history of translation. London: Routledge.

Zahid, I. (2020). Ketidakpatuhan maksim perbualan dan komunikasi berkesan dalam "Soal Rakyat”. Issues in Language Studies, 9(2), 33-51. 